
ACADEMIC YEAR 2018/2019

\author{
${ }^{1}$ Conny, ${ }^{2}$ Riska Devita \\ ${ }^{I}$ STKIP Budidaya Binjai \\ coniegeorgina@gmail.com \\ ${ }^{2}$ STKIP Budidaya Binjai \\ riskadevita5@gmail.com ${ }^{2)}$
}

\begin{abstract}
This research is conducted in order to improve students' writing ability uing Round Table Technique at Nineth grade of SMP Pabaku Stabat. The study is concerning with experimental study which discussed the effect of round table technique on students' ability in writing report text. It took place at SMP Pabaku Stabat. The subjects were the nineth grade students with the population of 132 students. 72 students were chosen as the sample and group into experimental and control group. Each group consisted of 36 students. The experimental group was taught with round table technique while the control one was taught without round table technique. A writing test was used to collect the data on the students' writing ability. The data collected were analyzed by using t-test. The result of the data analysis showed that the t-observed was 7,24. It was higher that the value of $t$-table $\left(t_{t}\right)$ is 1,66 for $5 \%$ and 2,38 for $1 \%$. This meant that the alternative hypothesis $(\mathrm{Ha})$ was accepted. It can be concluded that there is effect of round table technique on students' ability in writing report text of nineth grade of SMP Pabaku Stabat in academic year 2018/2019.
\end{abstract}

Keyword: Writing, Report Text, Round Table Technique.

\title{
INTRODUCTION
}

Writing is one kind of the activities done by the language learners and it isone of the productive skills. It cannot be produced without the ability of grammar and vocabulary of a writer. "Writing English is not a simple matter because when one is to write, he/she demonstrates not only his competence or his ability in grammar of English, but also his knowledge in the acceptable English rhetoric or the communicative aspects of writing in English." Horn by also states that writing is in the sense of the verb 'write'. Writing is making letters/ symbols on a surface, especially with a pen or a pencil on a paper.
As one kind of the language skills (productive language skills), writing plays a prominent role that is like household commodities consumed by everyone, especially for literate society. Considering the importance of written language, also points out that writing sentence structures and patterns must be carefully formulated, word choices are more precise, and ideas organized in a manner are readily coherent to the reader. The writing production can be good when it contains the components of writing skill, and it can deliver the message as good as possible. Briefly, the students have the obligation to send their 
writing become appropriate message to the reader.

Writing is not an easy activity and to master the writing is not easy too. In line with this idea, "Saddler wisely remarks that, a good writing is not only a hard work; it is an extremely complex and challenging mental task. It means that to understand and to master the writing need a hard work and mental readiness as the helping to take a part in the world of writing. In the context of writing, there are many interrelated components that should be understood by students as writers because writing is a complex act. Sturm and Koppenhaver also inform that composing for writing involves a complex thinking that must integrate multiple components including the topic or theme, choice of words, organization, purpose, audience, clarity, sequence, cohesion and transcription.

The complexity of a printed writing is not only determined by components mentioned above, but it is also determined by the kinds of writing. Different kinds of writings will show different difficulties.

Writing skill is categorized as the last of four language skills that should be mastered by all of the students. As the last of four language skills, writing is not only the difficult skill for students, but also an activity that is challenging for them. So that, they will be serious in the activities of writing.

In line with this idea, Flower and Hayes states that "writing is like juggling"-many things have to happen at once, and to keepthem all in the air, poses a challenge that a novice cannot readily meet.

SMA Swasta Persiapan Stabat is one of the State Senior High School in the Stabat
Kabupaten Langkat. As a formal school, it also provides English to the students, especially writing skill. In this school, writing has been taught since the first year of English teaching period. Based on School Based Curriculum (K13), the goal of the learning process is to develop the skills of communication and the basic competence of writing English refers to capability of students in expressing the meaning in monologue text or essays which use various written language accurately, fluently, and contextually in the forms of text such as report, narration, and analytical exposition.

Based on the writer's observation, the teacher at the nineth grade of SMP Pabaku Stabat taught English based on the curriculum and syllabus and report paragraphs was taught at the eleventh grade particularly at the first semester. In teaching writing, the teacher used Three-Phase Technique in teaching process. Three Phase Technique is a technique which consists of prewriting stage, writing stage, and revising. In this technique, the students are required to prepare themselves from pre writing stage to revising stage. The steps of the technique are the teacher showed to the students the example about report text, and then the teacher explained the elements in report text. Next step is that the students write a report text. The students who has finished writing could share their works with other students to check the grammar mistakes. The students submitted their works to their teacher and the teacher made correction and told it to the entire class.

However, the writing is teach maximally. The teacher had explained the material clearly and used some examples. But when the teacher let them write a report paragraphs, some of the students were not able to do it.The factors above made students' writing ability far from the curriculum expectation. The minimum score that should be reached by the students are 70 . 
Based on explanation above, ideally students of nineth grade of SMP Pabaku Stabat should be able to write a report text. It was because they had already known how to organize their ideas in written form. But, in fact, the teacher found that some of them still faced some problems and difficulties in English, especially in term of writing skill. Although they had already learned English since the first year of English teaching period, most of them had difficulty getting their own criteria of passing grade, even mostof them were not able to achieve it. Their writing scores are still far from the expectation of curriculum. The followings are the phenomena that the writer found during the researcher preliminary at of nineth Grade of SMP Pabaku Stabat:

a. Some of the students were not able to choose appropriate vocabulary in making report text.

b. Some of the students were not able to express their ideas in writing report text.

c. Some of the students were not able to use correct grammatical order in writing report text.

d. Some of the students were not able to develop their ideas into coherent paragraph in writing report text.

e. Some of the students were not able to construct the relationship of ideas within and between paragraphs clearly.

How ever, based on the symptoms above, thus the writer would like to offer a solution in order to make their writing ability better in writing report paragraphs. The solution is an appropriate technique in teaching writing, named Round Table technique.

According to Kagan, in the Round Table cooperative learning model, each team member writes one answer on a piece of paper that is passed around a table. Round Table is highly effective with creative writing and brainstorming activities. This structure encourages responsibility for the group and team building. Round Table technique is often used to solve the problem. This technique can also be used in teaching writing report paragraphs. "Round Table is a technique in writing that can be applied by point to each member ofa group to be a participant by making round table. So, the writer concluded that by using Round Table, students could give their own report about the topic in making report text.

Based on the phenomena depicted above, it could be concluded that most of the second year students are still problematic in terms of writing. Therefore, the writer was interested in investigating the problems above into a research entitled The Effect of Using Round Table Technique on Students'Ability in Writing Report Text of nineth Grade of SMP Pabaku Stabat".

Round Table is one of some cooperative learning which is developed by Spencer Kagan. "Round Table is a technique of writing that is applied by pointing each member to be aparticipant in their groups and they discuss a topic in round table. In addition, Round table technique isa technique useful for brain storming, reviewing, or practicing a skill. Students use a single sheet of paper and pen for each group. Students in the group respond in turn to a question or problem by stating their ideas on the paper.

This technique is useful as a content-related team building exercise. It means that, this technique can build students' to do more exercises, especially in writing skill. Like many other techniques, Round Table ensures that every student in the classroom is generating knowledge and contributing their ideas on the paper. Round Table can quickly transform students' idea because multiple groups are 
simultaneously engaged with their want in showing their thought.

Writing is a skill used to transfer information and to communicate to other humans by using written language. Writing is not an easy skill and activity. Writing is an activity of exploring the writer's thought to arrange the ideas into words which are communicated in meaning fulway. It means that the writer can share their ideas communicatively by using writing activity. Therefore, before writing, the writer needs to know the components of writing itself. In line with this idea, Reid states that writing is a complex skill, because there are some components that should be focused on writing, such as the purpose of writing and writer's knowledge of writing (paragraph's and pattern organization).

It means that, writing should be taught to the students to improve and stimulate the students' cognitive which is useful for students who learn language. Writing is produced by a writer as a tool to communicate to other with a various messages.

Regarding this idea, Nunan states that writing is aprocess and a product. Process means that the act of gathering ideas and working with them until they are presented in a manner that is polishedand comprehensible to readers, meanwhile, writing as a product means that the final pieces of writing such a book, has grown out of many steps which make up the process.

In teaching learning process, writing can give more chances to the students to create their ideas, to produce and to express what their arguments, explanations, and opinions in written language are. According to Raimes, writing can help everyone in reinforce the aspects in language such as: grammatical structures, idioms, vocabulary, etc. It means that, by using writing the students can understand more about grammatical structure rules, idioms, choice of words, etc. In line with this idea, Notion said that writing is an activity that can usefully be prepared by working in other skills of listening, speaking and reading. This preparation can make it possible for words that have been used receptively to come intoproductive use. It means that, writing activity is very useful to the students to help their other skills. Writing is the process so that it involves some activities and very time consuming. The writers do not always go directly from prewriting to drafting to revising to editing. They even often double back before they go forward. For example, a writer has left drafting and doubled back to prewriting when he thinks a new idea to add while he is drafting. He also probably think of a better way to phrase an idea while he is editing so that she has left editing and doubled back to revising.There is no obligation to complete one activity before starting another one and there is no predetermined order in which these activities must occur. Writing is not completely structured inprocess.

In short, the writing process involves some stages, such as; being motivated to write, getting ideas together, planning and outlining, making notes, making a first draft, revising, replanning, redrafting, editing, and getting ready for publication. Although generally the writing process contains these overall steps, the writing process is not a linier one; moving from planning to composing to revising to editing. Saughnessy describes the writing process as _a messy process that leads the clarity. Generally, every successes writing involves four writing process; planning or pre- writing, drafting, revising, and editing.

Report text is a text that presents information clearly and succinctly. Report text 
is a kind of texts to describe the way things are, with reference to arrange natural, man-made and social phenomena in our environment. The stages of a report are context-specific and relate very closely to its purpose.

It is always found in text book, newspaper, article, encyclopedia, etc. report text are similar to article, have a more formal, factual style, and each kind has its own special format and features.

The research hypothesis is formulated as follows:

$\mathrm{H}_{\mathrm{a}}$ : " There is effect of using Round Table technique on students' ability in writing report text of nineth grade of SMP Pabaku Stabat.

$\mathrm{H}_{0}$ : “ There is no effect of using Round Table technique on students' ability

in

\begin{tabular}{lccc}
\hline Class & Pre-test & Treatment & Post-test \\
\hline Experimental & $\mathrm{T} 1$ & $\mathrm{X}$ & $\mathrm{T} 2$ \\
\hline Control & $\mathrm{T} 1$ & $\Theta$ & $\mathrm{T} 2$ \\
\hline
\end{tabular}

The similar characteristics intended for both of classes were: the students have teach by the same teacher of English, the students have the same level, the students have the same program (science program), and the students have the same material about learning of writing. The sample of this research also can be seen as follow.

\begin{tabular}{lccc}
\hline \multirow{2}{*}{ Group } & \multirow{2}{*}{ Technique } & \multicolumn{2}{c}{ Samples } \\
\cline { 3 - 4 } Experimental & Round Table & $\mathrm{IX}_{1}$ & $\begin{array}{c}36 \\
\text { Students }\end{array}$ \\
\hline Control & Conventional & $\mathrm{IX}_{3}$ & $\begin{array}{c}36 \\
\text { Students }\end{array}$ \\
\hline & Total & & $\begin{array}{c}\mathbf{7 2} \\
\text { Students }\end{array}$ \\
\hline
\end{tabular}

For collecting the data, a writing test was given to the students. The test was administered to the students in both experimental and control group. They were pre-test and post-test. The design of the test was in essay form. The students have in structured to write a report text writing report text of nineth grade of SMP Pabaku Stabat.

\section{METHOD OF THE RESEARCH}

This research was conducted at SMP Pabaku Stabat Jl. Pringgodani, Ds Karang Rejo No. 813, Stabat Kabupaten Langkat. This research was conducted in the first semester on 2018.

In conducting the research, the writer conducted quantitative research design in particularly true experimental study. In this design there were two groups, each of which is chosen randomly. The first group was treated special and the other group is not. The group to be treated was called the experimental group and the group that not treated was called the control group.

based on the topic given by the researcher. The tests were given to both groups; experimental and control group. The students' ability in learning report text was analyzed by the collecting data in the tests.

Techniques of collecting data was the techniques or methods that can be used by researchers for collecting data. Techniques for appointing an abstract word and not embodied in objects, but their use only be seen through: questionnaires, interviews, observations, test, documentation, and others. Researchers can use one or a combination of these techniques depends on the problems encountered or studied. In this research, it use pre-test, treatment, and post-test.

T-Test was used to test the hypothesis of the research and statistical methods for determining the hypothesis test to be used must be adapted to the statistical assumptions, for example assumption of distribution and homogeneity of variants. 
For the normal distribution of data and homogenous hypothesis test using parametric statistical $t$ test according to the following equation:

$$
t=\frac{\bar{x}_{1}-\bar{x}_{2}}{\sqrt{\left[\frac{x_{1}^{2}+x_{2}^{2}}{n_{1}+n_{2}-2}\right]\left[\frac{1}{n_{1}}+\frac{1}{n_{2}}\right]}}
$$

Note:

$\bar{x}_{1}=$ deviation score of the experimental group

$\bar{x}_{2}=$ deviation score of the control group

$x_{1}{ }^{2}=$ the square of the deviation score of the experimental group

$x_{2}{ }^{2}=$ the square of the deviation score of the controlled group

$n_{1} \quad=$ the number of the students of the experimental group

$n_{2}=$ the number of the students of the controlled group

\section{DATA ANALYSIS AND DISCUSSION}

The followings were tables of scores taken from the result of writing test given to experimental and control groups. The test was given before and after the teaching activity, pretest and post-test.

From the data above, there was an increasing score gained from post-test compared with the pre-test score from 2340 into 2655.

From the data above, there was an increasing score gained from post-test compared with the pre-test score, from 2415 into 2545.

The mean of the score difference between pre-test score and post-test score in experimental group was 8,75 .

The mean of the score difference between pre-test score and post-test score control group was 3,61 .

The calculation shows that:

$\mathrm{X} 1=8,75$

$\begin{array}{lll}\mathrm{X} 2 & = & 3,61 \\ \mathrm{X}_{1}{ }^{2} & = & 368,75 \\ \mathrm{X}_{2}{ }^{2} & = & 230,56 \\ \mathrm{n} 1 & = & 36 \\ \mathrm{n} 2 & = & 36\end{array}$

e-ISSN 2621-010X

To analyze the data gained from the test, the writer used the t-test formula as the following:

$$
t=\frac{\bar{x}_{1}-\bar{x}_{2}}{\sqrt{\left[\frac{x_{1}^{2}+x_{2}^{2}}{n_{1}+n_{2}-2}\right]\left[\frac{1}{n_{1}}+\frac{1}{n_{2}}\right]}}
$$

The resultof the t-test calculation is as shown below:

$$
\begin{gathered}
t=\frac{8,75-3,61}{\sqrt{\left[\frac{368,75+230,56}{36+36-2}\right]\left[\frac{1}{36}+\frac{1}{36}\right]}} \\
t=\frac{5,14}{\sqrt{\left[\frac{599,31}{70}\right]-[0.06]}} \\
t=\frac{5,14}{\sqrt{8,56 x 0,06}} \\
t=\frac{5,14}{\sqrt{0,514}} \\
t=\frac{5,14}{0,71} \\
t=\mathbf{7 , 2 4}
\end{gathered}
$$

In this research, the writer used test (pretest and post-test) for collecting data. The purpose of the research was to know students' ability in writing report text by using Round Table technique. The first test was pre-test given before treatment. In pre-test, the students wrote a report text based on the topic given in 40 minutes. After that, the writer began to do the treatment by using Round Table in teaching writing report text and gave an exercise of writing. At the last meeting, the writer gave post-test for the students. The writer used classification to measure students' ability in writing report text taught by using Round Table technique and taught without Round Table 
technique. This research applied an objective test called writing test. The students' writing test was scored by calculating the five component scales (content, organization, vocabulary, language use and mechanics). After conducting the research, the researcher got the data of the students' scores in pre-test and post-test from both experimental and control group.

From the calculating of data analysis by using t-test it is got that the value of t-observed is 7,24 . Then to see whether the hypothesis of this studyis accepted or not, the value is compared with the value from t-table of distribution with $d f=70$ (since there is 36 students in each group, therefore degreeof freedom is $\left(\mathrm{n}_{1}+\mathrm{n}_{2}-2=36+36-2=70\right)$. Because there is $d f 70$ in table, so the writer decides to use $d f 70$. The table at $d f$ of 70 shows that the value of t-table $\left(t_{t}\right)$ is 1,66 for $5 \%$ and 2,38 for $1 \%$.

Theorytically, the alternative hypothesis (Ha) is accepted if the value of t-observed is greater than the value of $t$-table $\left(t_{o b s}>t_{t a b}\right)$. The finding above shows that $\mathrm{t}$-observed is greater than t-table $(7,24>2,00$ and 2,38). It means that the hypothesis $(\mathrm{Ha})$ is accepted.

The result of the study proves that there is effect of round table technique on students' ability in writing report text of nineth grade of SMP Pabaku Stabat in academic year 2018/2019.

\section{CONCLUSION AND SUGGESTION}

\section{Conclusion}

Based on the result of the analysis in the previous chapter, it can be concluded that the alternative hypothesis $\left(\mathrm{H}_{\mathrm{a}}\right)$ is accepted and the null hypothesis is rejected $\left(\mathrm{H}_{0}\right)$. It means that there is effect of round table technique on students' ability in writing report text. Based on the result, it can be drawn the conclusion that teaching writing report text can be taught by the use of round table technique.

\section{Suggestion}

Based on the data prescribed previously, the writer gives some suggestions as follows.

Students should learn other components or report text such as; language features and generic structures since the students' comprehending of these components influence the students' achievement of learning in writing a report text. Students should be firstly taught the use of past tense before they are taught how to write a report text.

\section{REFERENCES}

Anisatul Azizah Hasanah. 2011. Peningkatan Keterampilan Menulis Deskripsi melalui Model Kooperatif Tipe Round Table pada Siswa Kelas Xa SMA Muhammadiyah 4 Yogyakarta, Yogyakarta: UNY.

Christopher T. Arra, et. al. 2011. Journal of Education:Students' Preferences for Cooperative Learning Instructional Approaches: Considerations for College Teachers, Vol. 21.

David Nunan. 2000. Language Teaching Methodology: A Textbook for Teacher, Malaysia: Longman.

Depdiknas. 2013. School Based Curriculum K13, Jakarta: Depdiknas.

Hornby, Albert Sydney. 1974. Oxford Advanced Learner's Dictionary of Current English", Oxford: Oxford University Press.

Joy M. Reid. 1988. The Process of Composition. New Jersey: Prentice-Hall, Inc. 
Kagan, S. The Structural Approach to Cooperative Learning. Educational Leadership

Peter, Westwood. 2008. What Teacher Need to Know about Reading and Writing Difficulties. Victoria: Acer Press.

Raimes , Ann. 1983. Techniques in Teaching Writing. Oxford: Oxford University Press.

Rachmatul, 2013. Tehnik pengumpulan data dalam penelitian kuantitatif dan kualitatif.https://rachmatul4212.wo rdpress.com/2013/01/28/teknikpengumpulan-data-dalampenelitian-kuantitati9f-dankualitatif.Accessed on $28^{\text {th }}$ January

Syafi'i, Muhammad S. 2007. From Paragraphs to a Research Report: A Writing of English for AcademicPurposes, (Pekanbaru: Lembaga Bimbingan Belajar Syaf Intensive LBSI.

Tricia Hedge. 1988. Writing: Resource Book for Teachers. New York: Oxford University Press. 